\title{
Fish Ecology of the Alto Madre de Dios River Basin (Peru): Notes on Electrofishing Surveys, Elevation, Palm Swamp and Headwater Fishes
}

\author{
Ibon Tobes ${ }^{1,2}{ }^{(D}$, Adrián Ramos-Merchante ${ }^{3}$, Julio Araujo-Flores ${ }^{4,5,6} \mathbb{D}$, Andrea Pino-del-Carpio ${ }^{2}$, Hernán Ortega ${ }^{7}$ \\ and Rafael Miranda $2, * \mathbb{D}$
}

Citation: Tobes, I.;

Ramos-Merchante, A.; Araujo-Flores, J.; Pino-del-Carpio, A.; Ortega, H.; Miranda, R. Fish Ecology of the Alto Madre de Dios River Basin (Peru): Notes on Electrofishing Surveys, Elevation, Palm Swamp and Headwater Fishes. Water 2021, 13, 1038. https://doi.org/10.3390/ w13081038

Academic Editor: José Luis Sánchez-Lizaso

Received: 8 February 2021

Accepted: 7 April 2021

Published: 9 April 2021

Publisher's Note: MDPI stays neutral with regard to jurisdictional claims in published maps and institutional affiliations.

Copyright: (c) 2021 by the authors. Licensee MDPI, Basel, Switzerland. This article is an open access article distributed under the terms and conditions of the Creative Commons Attribution (CC BY) license (https:// creativecommons.org/licenses/by/ $4.0 /)$.
1 Centro de Investigación en Biodiversidad y Cambio Climático (BioCamb), Facultad de Ciencias del Medio Ambiente, Universidad Tecnológica Indoamérica, Quito EC170103, Ecuador; ibonto-bes@uti.edu.ec

2 Biodiversity Data Analytics and Environmental Quality Research Group, Department of Environmental Biology, University of Navarra, 31009 Pamplona, Spain; apino@alumni.unav.es

3 Department of Integrative Science, University of Huelva, Campus Universitario El Carmen, Avda. Andalucí s/n, 21071 Huelva, Spain; ramosadrian24@gmail.com

4 Centro de Innovación Científica Amazónica, Jr Cajamarca Cdra 1, Puerto Maldonado 17001, Peru; araujojm@wfu.edu

5 Center for Energy, Environment, and Sustainability, Department of Biology, Wake Forest University, 1834 Wake Forest Rd, Winston-Salem, NC 27109, USA

6 Colección Científica de Ictiología, Universidad Nacional Amazónica de Madre de Dios, Av. Jorge Chávez 1160, Puerto Maldonado 17001, Peru

7 Departamento de Ictiología, Museo de Historia Natural de la Universidad Nacional Mayor de San Marcos, Lima 15072, Peru; hortega.musm@gmail.com

* Correspondence: rmiranda@unav.es; Tel.: +3448-425600

\begin{abstract}
Our study analyzes the distribution of fish communities related to the environmental variables of the Alto Madre de Dios River, an Andean-Amazon watershed of southern Peru, between 300 and $2811 \mathrm{~m}$ a.s.l. within the Manu Biosphere Reserve. We provide new ecological and diversity data on fishes for these poorly studied rivers and new data for palm swamp habitats. With electric fishing techniques, we collected a total of 1934 fish specimens belonging to 78 species, 42 genera and 15 families. To assess main patterns of diversity we combined SIMPER and ANOSIM with canonical correspondence analysis to obtain an overview of the community structure of fish and their distribution related to aquatic habitats. Our results show an important shift on fish diversity at $700 \mathrm{~m}$ a.s.l. separating headwater and middle-lowland communities. Electrofishing was a hindrance due to the depth, flow and low conductivity of the rivers, but also allowed us to capture fish not observed with other techniques. We also compared the use of elevation with slope as an alternative variable for statistical analysis. Our results show that slope offers a solid and equivalent explanation for fish distribution variability, avoids redundance, and instead of giving geographical data offers ecologically solid information.
\end{abstract}

Keywords: Tropical Andes; Manu Biosphere Reserve; Astroblepus; Trichomycterus; Mauritia flexuosa

\section{Introduction}

Freshwater ecosystems are often referenced among those that are most altered and threatened by anthropogenic impacts [1] and their fauna is at greater risk than any other animal and plant groups [2]. In this respect, precise knowledge of ecological aspects like species distribution and requirements are a key point for conservation strategies, especially when the focal species are threatened or endangered [3]. Unfortunately, our limited taxonomic knowledge and incomplete information on species distributions for broad territories is very high and represents an insurmountable obstacle for documentation of imperilment and extinction of freshwater biodiversity [4]. In particular, fish assemblage variations in mountain streams of the Andes are poorly understood [5,6]. 
The Tropical Andes is regarded as the richest of the 25 recognized global biodiversity "hotspots". It includes Andean ecosystems above $500 \mathrm{~m}$ a.s.l., extending from Chile and Argentina, through Bolivia, Peru, Ecuador, to Colombia and Venezuela. This hotspot supports an estimated 45,000 plant and 3400 vertebrate species (excluding fishes), which represents about $15 \%$ and $12 \%$ of all globally known species, respectively, being nearly half of them endemic to the area [7].

Peru is home to 1064 fish species [8], more than the 7\% of all the globally known freshwater species. Most of them (more than 800) are found in the Amazonian Basin. Only during the first decade of the XXI century, 155 new species were named in Peru and the experts estimate the total number of Peruvian freshwater fishes at approximately 1200 species [8]. However, as seen before, there have been few ecological surveys focusing on fish and the majority point out the uneven level of knowledge for this group of vertebrates $[9,10]$, with some taxa itemized at the species level, whereas others routinely are catalogued at family level, order or even phylum [4].

Reviewing research on the Department of Madre de Dios where our study was carried out (Figure 1), Pitman et al. [11] reported that all the scientific studies generated for the department found that only $2.8 \%$ of the analyzed manuscripts focus on fish or hydrobiology. Only lichens received less attention than fish. Other research works regarding plants or mammals comprise $21.3 \%$ and $16.6 \%$ of the total scientific literature, respectively.

Streams of the Tropical Andes are also ecologically important as the headwaters of the megadiverse lowland river systems in South America [12]. They are responsible of delivering major loads of inorganic sediment and organic carbon to lowlands [13] and play a key role in the ecological processes along the Andes-to-Amazon fluvial continuum [14]. Furthermore, the Andean flank of the Amazon hosts the highest biodiversity rates and has been least affected by historical climate variability and land use [15].

However, the Andean-Amazonian piedmont is a rapidly changing landscape, part of the "arc of deforestation" [16], caused foremost by the expansion of cattle and soybean production [17]. The recent growth of human populations, the exploitation of natural resources and the proliferation of hydroelectric dams are leading to extensive reductions in habitats and subsequent impacts on rivers [18-20]. Fortunately, many opportunities for protecting these habitats yet exist, particularly in Peru, where entire river systems are still relatively intact and where there are few large dams and other major structural changes to river channels [21].

Our study area, the Alto Madre de Dios River Basin, in the south west of Peru, is an almost pristine basin. It is located in the Andean-Amazonian piedmont, in the transition zone of the Manu Biosphere Reserve, bordered on the northwest by the Manu National Park, and on the southeast by the Amarakaeri Communal Reserve, two important protected areas of the Peruvian Amazon. This region has long been known to tropical biologists as a region high in species diversity, as well as some of the world's largest expanses of pristine tropical forest [22].

Given the pessimistic predictions for the sustainability and conservation of the Andean biodiversity due to environmental alterations $[23,24]$, studies on the relationships among biotic and abiotic factors and the abundance and distribution of Andean fish are critical to document the primary characteristics of the original communities and thereby contribute to the delimitation of appropriate conservation areas and/or to recovery strategies.

One of the most frequent variables used for studying ecology and biodiversity distribution patterns is elevation. Ecologist all around the globe have demonstrated the strong correlation between altitude and changes in community composition, for plants [25], insects [26], amphibians [27], birds [28], and other organisms. Elevation is also commonly used for studying freshwater biodiversity distribution patterns along the watersheds [29], and together with the distance to the mouth or the distance to the source, they are among the most repeated variables for analyzing fish distribution patterns [10,30]. Nevertheless, the use of those geographical variables can be problematic. We aspire to discuss it and evaluate the use of slope as an alternative environmental variable. 


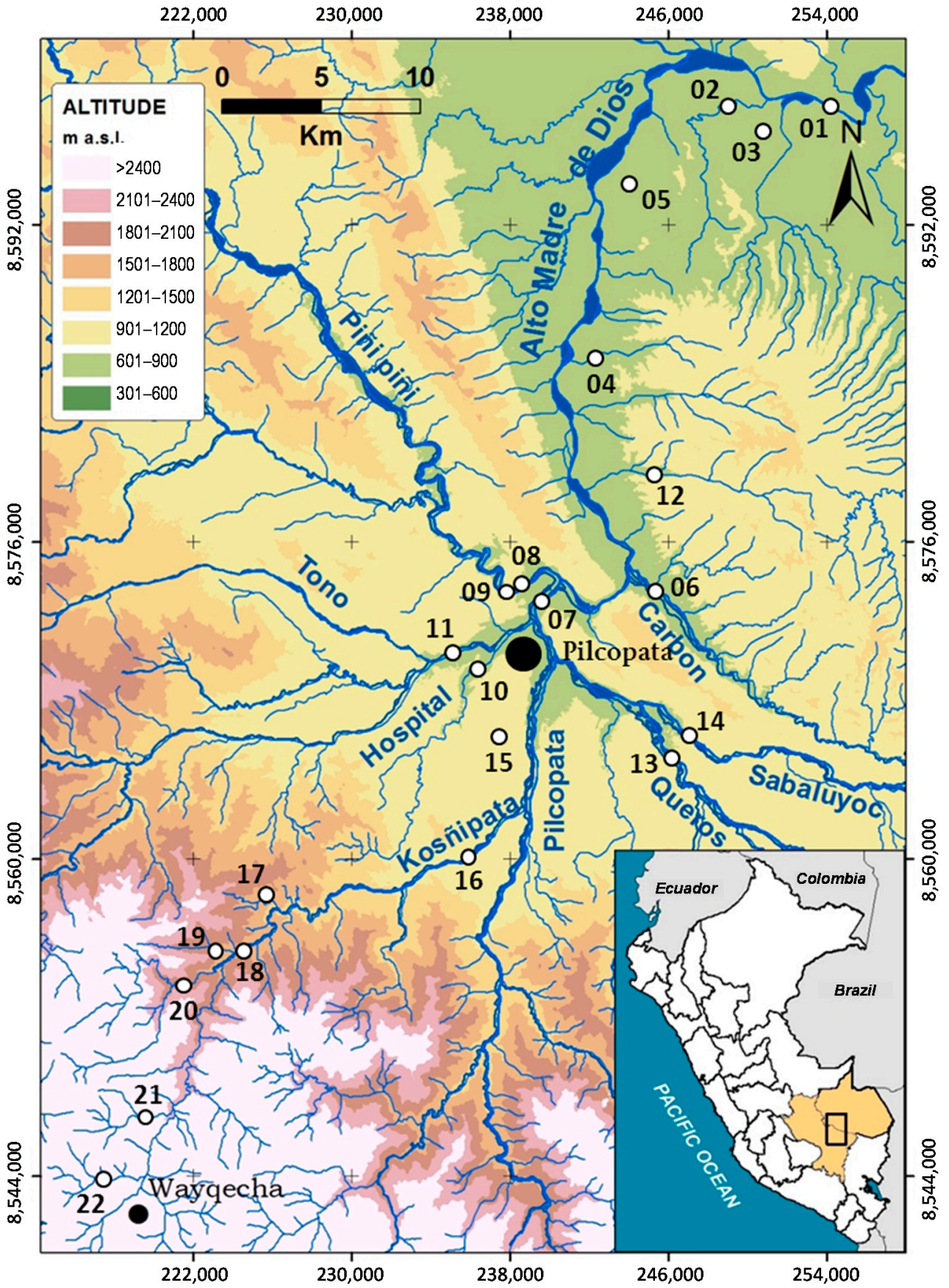

Figure 1. Sampling sites in the Alto Madre de Dios River, Peru (white circles).

In the present study we examine the freshwater ecology for the Alto Madre de Dios River focusing on its ichthyofauna and evaluate the environmental integrity of the studied ecosystems. Our specific objectives are to (1) describe spatial variation of fish assemblage of an unstudied Andean-Amazonian stream, (2) to identify patterns of association between fish assemblages and habitat variables, and to (3) discuss the use of elevation for ecological and fish distribution analysis.

\section{Materials and Methods}

\subsection{Study Area}

The Manu National Park has been considered one of the world's most important tropical protected areas since its creation in 1973 (Shepard et al., 2010). Located in the southern Peruvian Amazon rainforest constitutes the core of the Manu Biosphere Reserve 
and an IUCN World Heritage Site [31]. The southern buffer zone of Manu Biosphere Reserve includes the Alto Madre de Dios basin $\left(11^{\circ} 00^{\prime}-13^{\circ} 30^{\prime} \mathrm{S}, 73^{\circ} 30^{\prime}-68^{\circ} 30^{\prime} \mathrm{W}\right)$ (Figure 1). The river flows, south to north, for $275 \mathrm{~km}$ through the rainforest of Cusco and Madre de Dios Departments, draining an area of approximately $1600 \mathrm{~km}^{2}$. The altitude in the basin varies from up to 3500 to $300 \mathrm{~m}$ a.s.l. in the Manu River junction, spanning five Andean vegetation zones: puna (4500-3500 m), upper cloud forest (3500-2500 m), lower cloud forest (2500-1000 m), piedmont (1000-400 m) and lowlands (400-50 m) [32]. Our highest sampling site was located at $2411 \mathrm{~m}$ a.s.l. while to lowest was at $398 \mathrm{~m}$ a.s.1., $80 \mathrm{kms}$ downstream. Rivers flow through deep and narrow valleys and steep slopes from the source to around $700 \mathrm{~m}$ a.s.l., where the valleys open to wide and flat lowland floodplains. Flow regime is highly responsive to rainfall and presents the greatest discharge period from November to April, decreasing progressively in the dry season (from May to October). The rivers remain turbid through the year, with highest sediment loads during the rainy season.

Human population density in the Alto Madre de Dios valley is low, with scattered settlements that are under the administration of the village of Pilcopata in the District of Kosñipata (pop. 4790 in 2007, according to the Statistical National Institute of the Peruvian Government), Department of Cusco.

Nowadays, most of the land is still covered by primary Amazonian forest, although some areas have been deforested and are used for cattle raising. Tourism facilities-lodges and a network of forest trails - are used by a relatively low number of tourists in comparison with other lodges in Madre de Dios area [22].

\subsection{Field Sampling and Analysis}

Our survey was conducted on twenty-two sampling sites in June 2012, during the dry season (Figure 1). The following environmental variables were recorded at each site using a multiparametric probe (Hanna Instrument, HI 98129 Combo Waterproof, Woonsocket, RI, USA): conductivity $(\mu \mathrm{S} / \mathrm{cm})$, water temperature $\left({ }^{\circ} \mathrm{C}\right)$, and $\mathrm{pH}$. Characterization of habitat structure was done using transects according to Armantrout (1998), and included depth $(\mathrm{m})$, width $(\mathrm{m})$, water velocity $\left(\mathrm{m} \cdot \mathrm{s}^{-1}\right)$, percent tree canopy shading and dominant substrate categorized as fines $(<2 \mathrm{~mm})$, gravels $(\sim 2-64 \mathrm{~mm})$, pebbles $(\sim 64-256 \mathrm{~mm})$, boulders $(>256 \mathrm{~mm})$, or bedrock and concrete. Additionally, two habitat quality indices were measured: Qualitative Habitat Evaluation Index-QHEI (Rankin, 1989), and Andean adapted version of the riparian forest quality index QBR (Acosta et al., 2009) (Table 1). QHEI jointly considers different habitat parameters, such as bottom substrate and embeddedness, instream structure, velocity and depth regime, canopy cover, channel alteration and pool/riffle or run/bend ratios. QBR index includes aspects of the riparian forest such as total riparian vegetation cover, cover structure, cover quality and channel alterations.

Fish sampling was carried out in wadeable stream stretches $(<1 \mathrm{~m}$ of height) by electrofishing surveys, using a backpack electrofishing gear (Hans Grassl model IG200/2D, 300-600 V, 0.2-2 A). Surveys was conducted following a single-run depletion methodology and estimating fish abundance based on catch per unit effort (CPUE) (Meador, McIntyre \& Pollock, 2003). Collected fish were anesthetized and subsequently counted, measured to the nearest $0.1 \mathrm{~cm}$ total length (TL), weighed with a digital scale to an accuracy of $0.05 \mathrm{~g}$ and released after the survey, except for some voucher specimens kept to confirm identification.

Voucher specimens were deposited in the fish collection of the Natural History Museum of National University of San Marcos (Lima, Peru). In the laboratory, fish were preserved in alcohol (75\%) and identified by Ana María Cortijo, Jessica Espino and Hernán Ortega, members of the Department of Ichthyology of Museum. Scientific names were validated according to W. N. Eschmeyer's Catalog of Fishes [33]. 
Table 1. Sampling sites and environmental variables in Alto Madre de Dios River, Peru.

\begin{tabular}{|c|c|c|c|c|c|c|c|c|c|c|c|c|}
\hline Code & River Place & Date & Alt & $\mathrm{pH}$ & Ta & Tw & $\mathrm{Cd}$ & Wh & $\mathrm{Dh}$ & Vc & QBR & QHEI \\
\hline $01 R$ & Aguas Calientes & 13 June 2012 & 398 & 7.95 & 24.3 & 21.7 & 105 & 18.2 & 25.1 & 0.51 & 100 & 72 \\
\hline $02 R$ & Shintuya & 12 June 2012 & 424 & 8.07 & 24.4 & 24.4 & 99 & 11.2 & 13.7 & 0.23 & 90 & 72 \\
\hline 03A & Anaconda & 13 June 2012 & 428 & 7.37 & 26.4 & 21.4 & 119 & 3.45 & 16.8 & 0.05 & 95 & 61 \\
\hline 04Q & Mascuitania & 14 June 2012 & 459 & 6.82 & 29.0 & 25.4 & 44 & 7.86 & 25.6 & 0.25 & 85 & 67 \\
\hline $05 \hat{Q}$ & Puente a $\mathrm{km} \mathrm{2,5}$ & 14 June 2012 & 462 & 8.03 & 26.1 & 22.4 & 169 & 5.54 & 18.7 & 0.15 & 100 & 74 \\
\hline $06 \widehat{R}$ & Carbón & 11 June 2012 & 499 & 8.78 & 26.3 & 25.3 & 102 & 14.4 & 34.5 & 0.41 & 100 & 85 \\
\hline 07R & Pilcopata & 10 June 2012 & 511 & 6.94 & 24.8 & 25.0 & 119 & 15.7 & 15.6 & 0.04 & 100 & 74 \\
\hline 08R & Piñi-Piñi & 7 June 2012 & 518 & 6.86 & 22.3 & 22.0 & 131 & 6.86 & 44.1 & 0.19 & 100 & 88 \\
\hline 09Q & Villa Carmen & 7 June 2012 & 518 & 7.20 & 22.3 & 20.6 & 126 & 4.51 & 5.11 & 0.13 & 100 & 62 \\
\hline $10 \widehat{R}$ & Hospital & 8 June 2012 & 547 & 7.63 & 23.1 & 19.9 & 26 & 28.3 & 36.6 & 0.74 & 100 & 84 \\
\hline $11 R$ & Tono & 8 June 2012 & 551 & 7.70 & 19.1 & 18.5 & 50 & 6.94 & 22.1 & 0.30 & 100 & 68 \\
\hline $12 \mathrm{R}$ & Salvación & 11 June 2012 & 558 & 7.26 & 24.0 & 23.2 & 33 & 4.42 & 30.1 & 0.39 & 100 & 66 \\
\hline $13 \mathrm{R}$ & Queros & 9 June 2012 & 587 & 8.00 & 20.0 & 18.3 & 61 & 10.4 & 39.5 & 0.31 & 80 & 82 \\
\hline $14 \mathrm{R}$ & Sabaloyacu & 9 June 2012 & 593 & 7.70 & 19.7 & 21.2 & 44 & 22.9 & 31.0 & 0.43 & 100 & 87 \\
\hline $15 \mathrm{~A}$ & Aguajal & 17 June 2012 & 622 & 5.77 & 23.9 & 22.0 & 26 & 2.49 & 57.4 & 0.04 & 50 & 63 \\
\hline $16 \mathrm{R}$ & Asunción & 10 June 2012 & 720 & 7.40 & 26.4 & 19.3 & 65 & 5.16 & 19.9 & 0.32 & 100 & 78 \\
\hline 17Q & Quitacalzon & 16 June 2012 & 1064 & 7.83 & 20.9 & 18.7 & 52 & 4.07 & 31.4 & 0.45 & 100 & 88 \\
\hline $18 \widehat{R}$ & Kosñipata & 16 June 2012 & 1347 & 7.53 & 22.2 & 16.0 & 89 & 6.42 & 24.4 & 0.15 & 95 & 70 \\
\hline $19 \mathrm{R}$ & San Pedro & 16 June 2012 & 1394 & 7.81 & 20.1 & 18.5 & 43 & 7.74 & 49.4 & 0.48 & 95 & 88 \\
\hline $20 \mathrm{R}$ & Unión & 17 June 2012 & 1673 & 7.72 & 20.2 & 15.3 & 64 & 8.41 & 32.0 & 0.72 & 75 & 66 \\
\hline $21 Q$ & Wayquecha & 18 June 2012 & 2218 & 7.40 & 17.3 & 11.4 & 51 & 3.99 & 30.2 & 0.83 & 100 & 84 \\
\hline $22 \hat{Q}$ & Pacchayoc & 18 June 2012 & 2411 & 4.41 & 16.1 & 11.7 & 188 & 6.11 & 23.9 & 0.89 & 100 & 82 \\
\hline
\end{tabular}

Alt: Altitude $(\mathrm{m})$, Ta: Air temperature $\left({ }^{\circ} \mathrm{C}\right)$, Tw: Water temperature $\left({ }^{\circ} \mathrm{C}\right), \mathrm{Cd}$ : Water conductivity $\left(\mu \mathrm{S} \cdot \mathrm{cm}^{-1}\right), \mathrm{Wh}: \mathrm{Mean}$ width $(\mathrm{m}), \mathrm{Dh}: \mathrm{Mean}$ depth $(\mathrm{cm})$, Vc: mean water velocity $\left(\mathrm{m} \cdot \mathrm{s}^{-1}\right)$, QBR: riparian forest quality index and QHEI: qualitative habitat evaluation index.

\subsection{Data Analysis}

From fish community compositional data, richness (Margalef's index $R=(S-1) / \ln N)$, and diversity (Shannon-Wiener index $\mathrm{H}^{\prime}=-\sum \mathrm{pi} \log ^{2} \mathrm{pi}$, and Simpson's index $\mathrm{D}=\sum \mathrm{pi}^{2}$ ) measures were calculated, where pi is the proportion of species " $\mathrm{i}$ " at a given site, $\mathrm{N}$ is the total number of collected specimens, and $S$ is the number of species [34].

First, polynomial regressions were set among the mentioned indices and elevation, distance to the mouth or slope. We wanted to describe and compare patterns of diversity considering these three variables related to location along the basin.

Second, several multiparametric statistical approaches were used to establish the main spatial patterns in the fish community composition [35]. To detect patterns among fish communities, we used a permutation-based test with a nonparametric one-way analysis of similarity (ANOSIM) using a Bray-Curtis similarity index based on abundance data [36,37]. The ANOSIM statistic compares the mean of ranked dissimilarities among groups to the mean of ranked dissimilarities within groups. An R-value close to 1 suggests dissimilarity among groups while an $\mathrm{R}$ value close to 0 suggests an even distribution of high and low ranks within and among groups. Post-hoc tests with Bonferroni correction in $p$-values (which were multiplied by the number of comparisons) are done. This correction is very conservative (produces large $p$-values). The sequential Bonferroni option does not output corrected $p$-values, but significance is decided based on step-down sequential Bonferroni, which is slightly more powerful than simple Bonferroni. If ANOSIM revealed a statistically significant result, the relative contribution of each species to group dissimilarities was quantified using a similarity percentage analysis (SIMPER), with a cut-off criterion of 90\% (Bray-Curtis similarity index), to identify subsets of the most important species [36]. SIMPER calculates the average Bray-Curtis dissimilarity among all pairs of inter-group samples, expressed in terms of the average contribution from each species. Previously, we created three categorical variables (type of mass of water (river vs. stream), elevation (upstream-downstream $700 \mathrm{~m}$ ), and stream order). Fish assemblages were compared considering these three categories.

For the choice of linear or unimodal analysis, a preliminary DCA (Detrended Correspondence Analysis) was performed [38]. This analysis evaluates the species turnover (the length of gradients) through the first DCA axis. The criterion for choosing linear vs. unimodal ordinations models is to obtain a SD $<3$ [39]. Our results showed a SD $>3$ 
because of the large number of species and their frequency of occurrence. To examine relationships between community composition and several environmental variables a Canonical Correspondence Analysis (CCA, Unimodal response; length of gradient SD > 3) was used through the program CANOCO $4.5[39,40]$ based on DCA results. To reduce the number of graphics and considering the similar patterns shown, altitude was selected over distance to mouth $(r=0.964, p$-value $<0.01)$ as representant of the geographical variables, to compare it with slope. Two parallel CCA were carried out with altitude or slope as key variables related to location along the headwater-downstream gradient. This direct gradient analysis technique provides ordination axes linearly related to the explanatory variables. The main result is a scatterplot ordination diagram displaying the pattern of fish assemblage variation along the environmental variables shown as vectors. Vector direction and length indicate the relative magnitude and influence of a particular variable on fish assemblages. The significance of the analyses was assessed by a permutation test with 1000 random permutations. Habitat structure and water quality variables were also included in the analysis. To improve linearity, environmental variables were log transformed. Proportional data and abundance fish data were transformed (arcsine and root transformed, respectively). Peebles was removed to avoid a high variance inflation factor (VIF) [41].

All multiparametric analysis were done for species that were captured in more than two sites (i.e., $10 \%$ occurrence) and were performed using the R project software version 3.2.3 [42] with the package "vegan" version 2.3-3 [43] except in the case of CCA which had been developed in CANOCO 4.56 [40].

Finally, fish species have been classified according to their trophic specialization [6,44,45], with the aim to analyze the distribution of these trophic groups in the elevation gradient.

\section{Results}

A total of 1934 specimens were collected, and 78 fish taxa were identified belonging to 43 genera and 14 families (Dataset S1). Twenty-seven species were undetermined, ten were identified as species affinis, and 41 species were correctly identified. Characids were the most diverse family with $43 \%$ of the species, followed by loricarids $(14 \%)$, trichomycterids $(8 \%)$, astroblepids, cichlids and heptapterids (7\% each one) and crenuchids $(3 \%)$. The remaining fish belonged to ten families with only one represented species.

Regarding diversity indices, values presented a marked altitudinal pattern. ShannonWiener and Margalef's indices showed negative correlations with altitude, distance to the mouth and slope, whereas Simpson's index showed positive correlation (Figure 2). Site 13 presented the highest diversity and hosted alone $28 \%$ of the total fish species ( 22 species). On the other hand, highest sites, 21 and 20, only had two species (Astroblepus sp. and Trichomycterus sp.). Finally, site 15 significantly different from the rest of the sampling points. It was a swamp ecosystem isolated from the main river and due to its unique environmental characteristics, it was discarded for subsequent analysis.

Results of one-way ANOSIM showed significant differences in community composition as indicated the high $\mathrm{R}$ values (global R: $0.786, p<0.001$ ) with the cut-off point at $700 \mathrm{~m}$ a.s.l. This makes fish composition upstream and downstream $700 \mathrm{~m}$ a.s.l. well distinguishable. Mass of water and stream order showed not significant differences (global R: 0.04 and R: 0.22 , respectively; $p>0.05$ ). The SIMPER procedure indicated that using three species was possible to explain more than $38 \%$ of variation among elevation categories. Astroblepus, Trichomycterus and Knodus were the most important species explaining the variation in community composition (Table 2). 

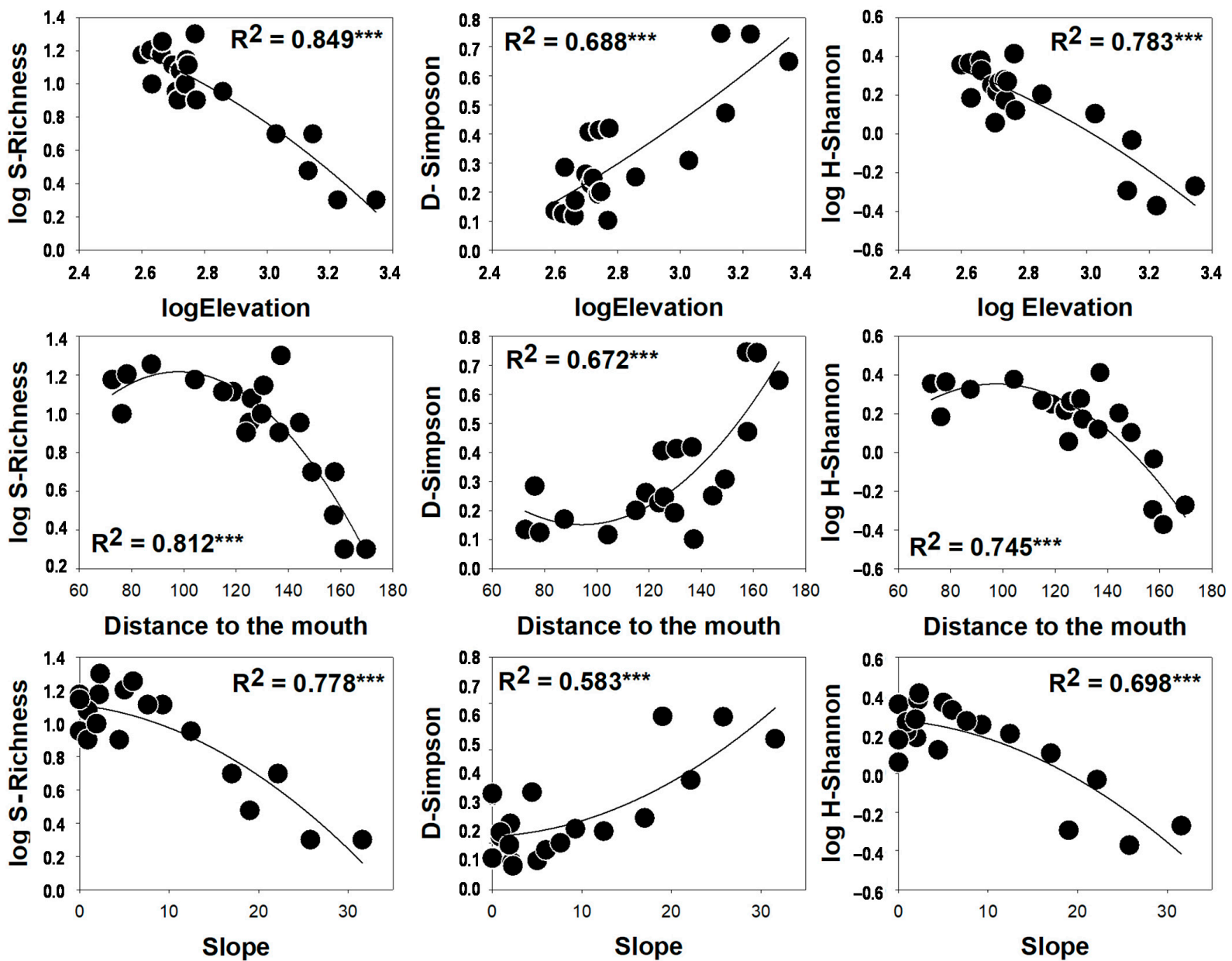

Figure 2. Estimates of the fish community diversity indices along the Alto Madre de Dios River, regarding to elevation, distance to the mouth and slope of sampling points. ${ }^{* * *}$ significative coefficient of determination $\left(\mathrm{R}^{2}\right)$.

Table 2. Relative abundance of taxa presents under (U) and above (A) $700 \mathrm{~m}$ of elevation. Taxa are ordered by their overall weight in the SIMPER analysis (taxa showed with a cut-point of $90 \%$ of contribution). Percent of contribution of each taxon accord to SIMPER is show for each group (\%contri). In the last row richness of each category of groups are shows.

\begin{tabular}{cccc}
\hline \multicolumn{4}{c}{ Elevation-700 m } \\
\hline Taxa & \% Contri. & U & A \\
\hline Astroblepus & 18.36 & 1.03 & 9.00 \\
Trichomycterus & 10.76 & 0.78 & 5.78 \\
Knodus & 8.91 & 3.92 & - \\
Chaetostoma & 7.67 & 3.54 & 1.93 \\
Creagrutus & 6.35 & 3.09 & - \\
Bryconamericus & 6.01 & 1.84 & 2.64 \\
Ceratobranchia & 5.88 & 3.22 & - \\
Astyanax & 5.26 & 2.45 & - \\
Ancistrus & 4.57 & 2.48 & - \\
Bujurquina & 3.42 & 1.73 & - \\
Hemibrycon & 3.36 & 1.63 & - \\
Characidium & 3.01 & 1.33 & - \\
Aphyocharax & 2.67 & 1.52 & - \\
Rineloricaria & 2.36 & 1.05 & - \\
Hoplias & 1.96 & 0.87 & \\
\hline
\end{tabular}


The relationship between fish and environmental variables are shown in Figure 3 and Tables 3 and 4 . The importance of environmental variables is indicated by the marginal effect values $\left(\lambda_{\mathrm{A}}\right)$ : for both analysis conductivity $(0.22)$, boulders $(0.25)$, water velocity $(0.25)$ and water temperature (0.38) were most significant. The variables with the highest marginal effect were slope (0.44) for the first CCA (Table 3a) and elevation (0.59) for the second CCA (Table 3b).

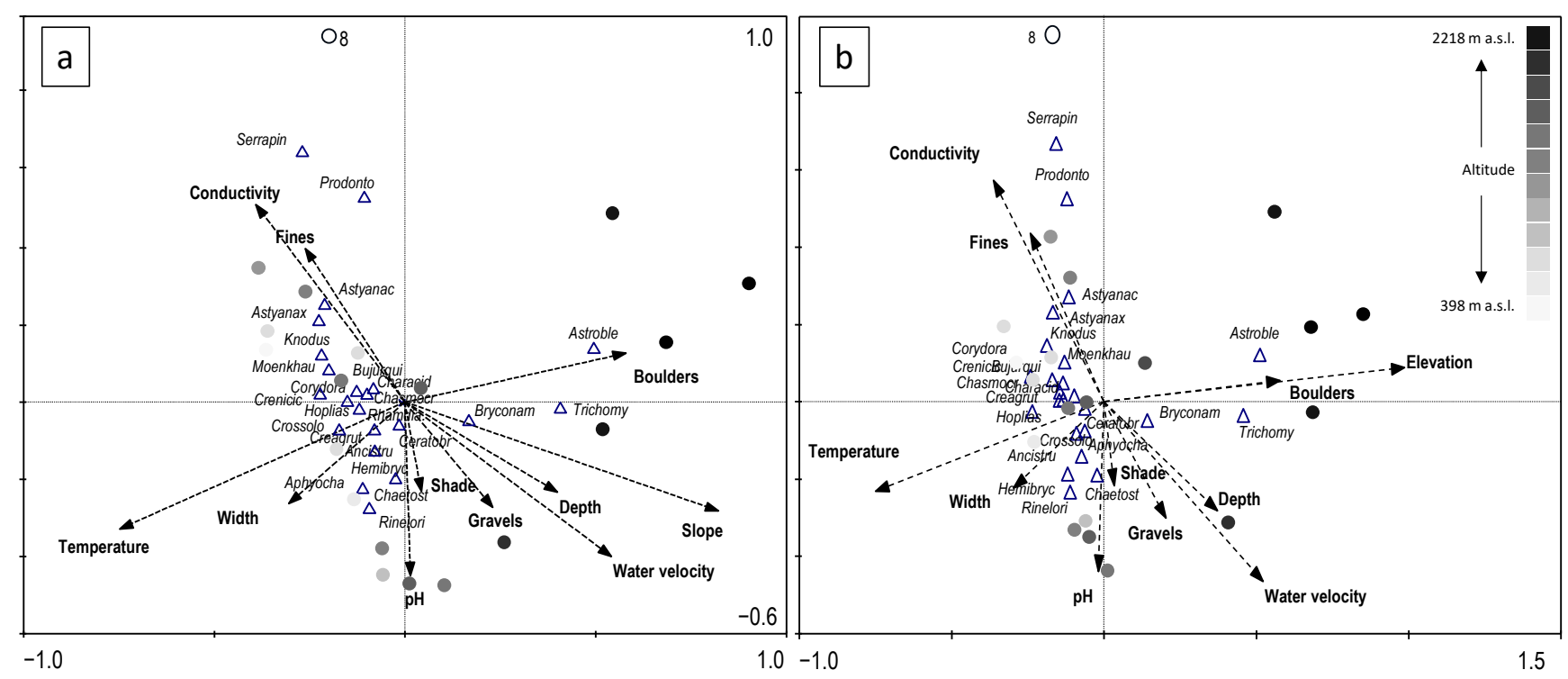

Figure 3. Triplot of results of canonical correspondence analysis carried out with slope (a) or elevation (b) as key variables related to location, showing site scores (circles), the environmental variables (vectors) and fish abundances (triangles) on the first two canonical axes. The code for site scores and environmental variables refers to sampling sites according to Table 1.

Table 3. Results of canonical correspondence analyses (CCA) carried out with slope (a) or elevation (b) as key variables related to location along the headwater-downstream gradient, showing canonical coefficients and weighted intraset correlation coefficients of explanatory variables with the first two axes of the CCA. Importance of environmental variables using marginal effects are shown $\lambda_{\mathrm{A}}$.

\begin{tabular}{|c|c|c|c|c|c|}
\hline (a) Slope & Marginal Effects & \multicolumn{2}{|c|}{ Intraset Correlations } & \multicolumn{2}{|c|}{ Regression/Canonical Coefficients } \\
\hline Groups & $\lambda_{\mathrm{A}}$ & CCA1 & CCA2 & CCA1 & CCA2 \\
\hline Slope & 0.44 & 0.786 & -0.261 & 0.755 & -0.114 \\
\hline Water temperature & 0.38 & -0.715 & -0.304 & -0.418 & -0.433 \\
\hline Water velocity & 0.25 & 0.517 & -0.370 & 0.047 & 0.002 \\
\hline Boulders & 0.25 & 0.554 & 0.118 & 0.006 & 0.111 \\
\hline Conductivity & 0.22 & -0.374 & 0.472 & 0.007 & 0.987 \\
\hline Depth & 0.19 & 0.382 & -0.216 & -0.076 & 0.377 \\
\hline Fines & 0.15 & -0.250 & 0.368 & -0.149 & 0.282 \\
\hline Width & 0.14 & -0.291 & -0.243 & -0.132 & 0.064 \\
\hline $\mathrm{pH}$ & 0.13 & 0.014 & -0.415 & -0.090 & -0.662 \\
\hline Gravels & 0.07 & 0.220 & -0.252 & 0.018 & 0.236 \\
\hline Shade & 0.07 & 0.041 & -0.214 & -0.266 & -0.289 \\
\hline (b) Elevation & Marginal Effects & \multicolumn{2}{|c|}{ Intraset Correlations } & \multicolumn{2}{|c|}{ Regression/Canonical Coefficients } \\
\hline Groups & $\lambda_{\mathrm{A}}$ & CCA1 & CCA2 & CCA1 & CCA2 \\
\hline Elevation & 0.59 & 0.963 & 0.081 & 1.069 & 0.077 \\
\hline Water temperature & 0.38 & -0.730 & -0.213 & 0.189 & -0.330 \\
\hline Water velocity & 0.25 & 0.510 & -0.427 & 0.074 & -0.032 \\
\hline Boulders & 0.25 & 0.563 & 0.051 & 0.091 & -0.010 \\
\hline Conductivity & 0.22 & -0.354 & 0.526 & -0.068 & 1.064 \\
\hline Depth & 0.19 & 0.364 & -0.259 & -0.080 & 0.402 \\
\hline Fines & 0.15 & -0.236 & 0.400 & 0.045 & 0.287 \\
\hline Width & 0.14 & -0.289 & -0.205 & -0.084 & 0.184 \\
\hline $\mathrm{pH}$ & 0.13 & -0.018 & -0.403 & 0.164 & -0.787 \\
\hline Gravels & 0.07 & 0.198 & -0.276 & -0.035 & 0.261 \\
\hline Shade & 0.07 & 0.034 & -0.199 & -0.083 & -0.250 \\
\hline
\end{tabular}


Table 4. Summary statistics table for CCA ordination presented, with slope (a) or elevation (b) as key variables.

\begin{tabular}{ccccc}
\hline CCA Axis & $\mathbf{1}$ & $\mathbf{2}$ & $\mathbf{3}$ & $\mathbf{4}$ \\
\hline $\begin{array}{c}\text { (a) Slope } \\
\text { Eingenvalues }\end{array}$ & 0.579 & 0.264 & 0.167 & 0.126 \\
$\begin{array}{c}\text { Species-environmental correlations } \\
\text { Cumulative percentage variance } \\
\text { of species data }\end{array}$ & 0.956 & 0.924 & 0.884 & 0.950 \\
of species-environmental relation & 27.9 & 40.6 & 48.7 & 54.7 \\
CCA Axis & 38.4 & 55.9 & 67.0 & 75.4 \\
\hline (b) Elevation & $\mathbf{1}$ & $\mathbf{2}$ & $\mathbf{3}$ & $\mathbf{4}$ \\
\hline Eingenvalues & 0.597 & 0.263 & 0.170 & 0.132 \\
Species-environmental correlations & 0.976 & 0.918 & 0.903 & 0.931 \\
Cumulative percentage variance & & & & \\
of species data & 28.8 & 41.5 & 49.7 & 56.0 \\
of species-environmental relation & 38.8 & 55.9 & 67.0 & 75.5 \\
\hline
\end{tabular}

For (a) Significance of the axis by the Monte Carlo permutation test is given by $\mathrm{F}=3.10(p<0.05)$. All canonical axes were significant. Values in bold indicate significant difference at $p<0.05$. For (b) Significance of the axis by the Monte Carlo permutation test is given by $\mathrm{F}=3.23(p<0.05)$. All canonical axes were significant. Values in bold indicate significant difference at $p<0.05$.

Outcomes were equivalent using slope and elevation as main variables, therefore, only results for CCA with slope are described next. The inertia in the assemblage composition in the studied sites was 0.579 for axis 1, 0.264 for axis 2, 0.167 for axis 3 and 0.126 for axis 4 . The CCA ordination revealed strong relationships between species abundances and measured environmental variables explaining $72.6 \%$ of species distribution. The first canonical axis (axis 1) accounted for $38.4 \%$ of the variation in the data set, the second axis (axis 2) accounted for $17.5 \%$ of the variation in the data set. An unrestricted Monte Carlo permutation test indicated that all canonical axes were significant $(p<0.05)$.

First Canonical Correspondence Analysis CCA1 eigenvalue accounts 0.579 and it is composed by slope, boulders and water velocity on the positive side and water temperature on the opposite side (Figure 3a). First Canonical Correspondence Analysis was interpreted as a longitudinal gradient from high to lowlands with sites above $700 \mathrm{~m}$ a.s.l. being distributed on the right area of the graph (except for site 12, slightly right from the axis) and sites below that altitude spread in the left area. Second Canonical Correspondence Analysis CCA2 (eigenvalue $=0.264$ ) is dominated by conductivity on the positive side and $\mathrm{pH}$ and water temperature on the negative side. Second Canonical Correspondence Analysis was interpreted as hydrochemical parameters (Table 3a; Figure 3a).

On the right area of the graph (Figure 3a) a first species group composed by Trichomycterus (Figure 4) and Astroblepus genera (Figure 5) was separated from the remaining and it was positively related to headwaters showing distinctive features: high velocities of water, big boulders and lower temperatures. Bryconamericus genera species were also related to these headwater streams, although they do not appear so high in the altitudinal gradient. A second group of fish represented by Serrapinnus, Prodontocharax, Astyanax, Astyanacinus and Knodus genera, located on the top-left area of the graph, was positively related to still waters with low velocities, higher conductivities and fine substrates (mainly sands). A third cluster, located on the top-left area of the graph, included Rineloricaria, Chaetostoma, Aphyocharax, Hemibrycon, Ancistrus, Creagrutus and Crossoloricaria. They were related to open places with highest water temperatures and wide riverbeds. The rest of the genera were distributed between these two groups along the first axis on the left of the graph, including Hoplias, Rhamdia, Chasmocranus and Characidium.

Attending to fish distribution and trophic specialization [6] along the altitudinal gradient (Figure 6), no fish were found above $2200 \mathrm{~m}$ a.s.l. Astroblepus and Trichomycterus were the only genus found on highest reaches (above $1400 \mathrm{~m}$ a.s.l.), feeding exclusively on invertebrates. Even though they appear tightly related to headwaters, they were found all along the basin with occasional and scarce occurrence also in lowland streams. At $1400 \mathrm{~m}$ a.s.l. three new genera appeared: one invertivorous Bryconamericus, and the 
first two herbivore-detritivores Chaetostoma and Ancistrus genera. Next invertivorous Characidium genus was found below $1100 \mathrm{~m}$. Above the $700 \mathrm{~m}$ other three invertivorous genera were found: Rhamdia, Creagrutus and Chasmocranus. The rest of the fish taxa were found below $622 \mathrm{~m}$, representing most of the diversity. The first piscivorous species, Hoplias malabaricus and Crenicichla semicincta were found at this altitude.
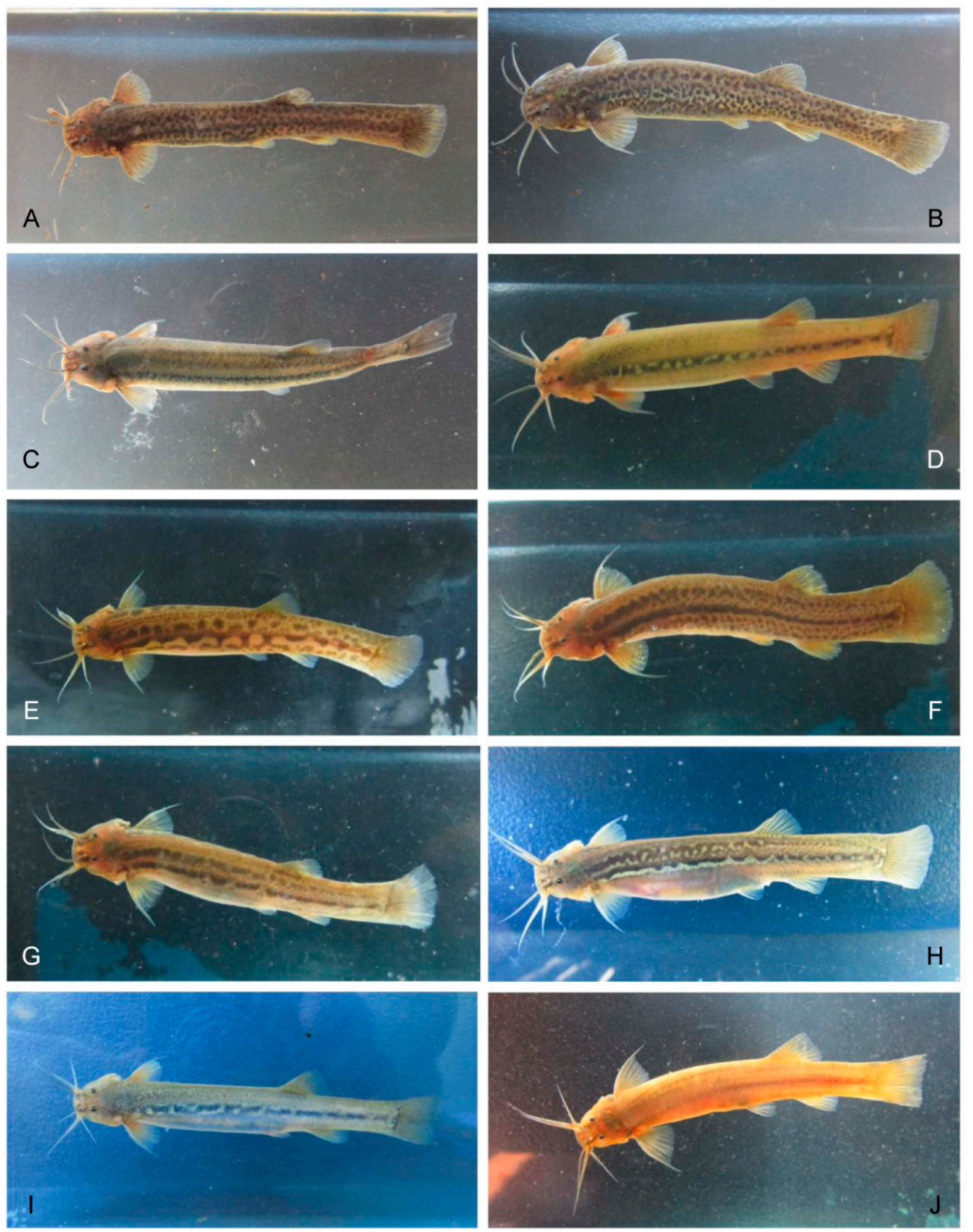

Figure 4. Species and morphotypes of genus Trichomycterus collected in the upper Madre de Dios River. (A,B) Trichomycterus sp.3 collected on Américo stream (21Q), (C) Trichomycterus sp.2 collected on Unión River (20R), (D) Trichomycterus sp.2 collected on San Pedro River (19R), (E) Trichomycterus sp.3 collected on Quitacalzon stream (17Q), (F,G) Trichomycterus sp.5 collected on Quitacalzon stream (17Q), (H) Trichomycterus sp.4 collected on Salvación River (12R), (I) Trichomycterus sp.6 collected on Kosñipata River (16R), and (J) Trichomycterus sp.1 collected on Queros River (13R). 

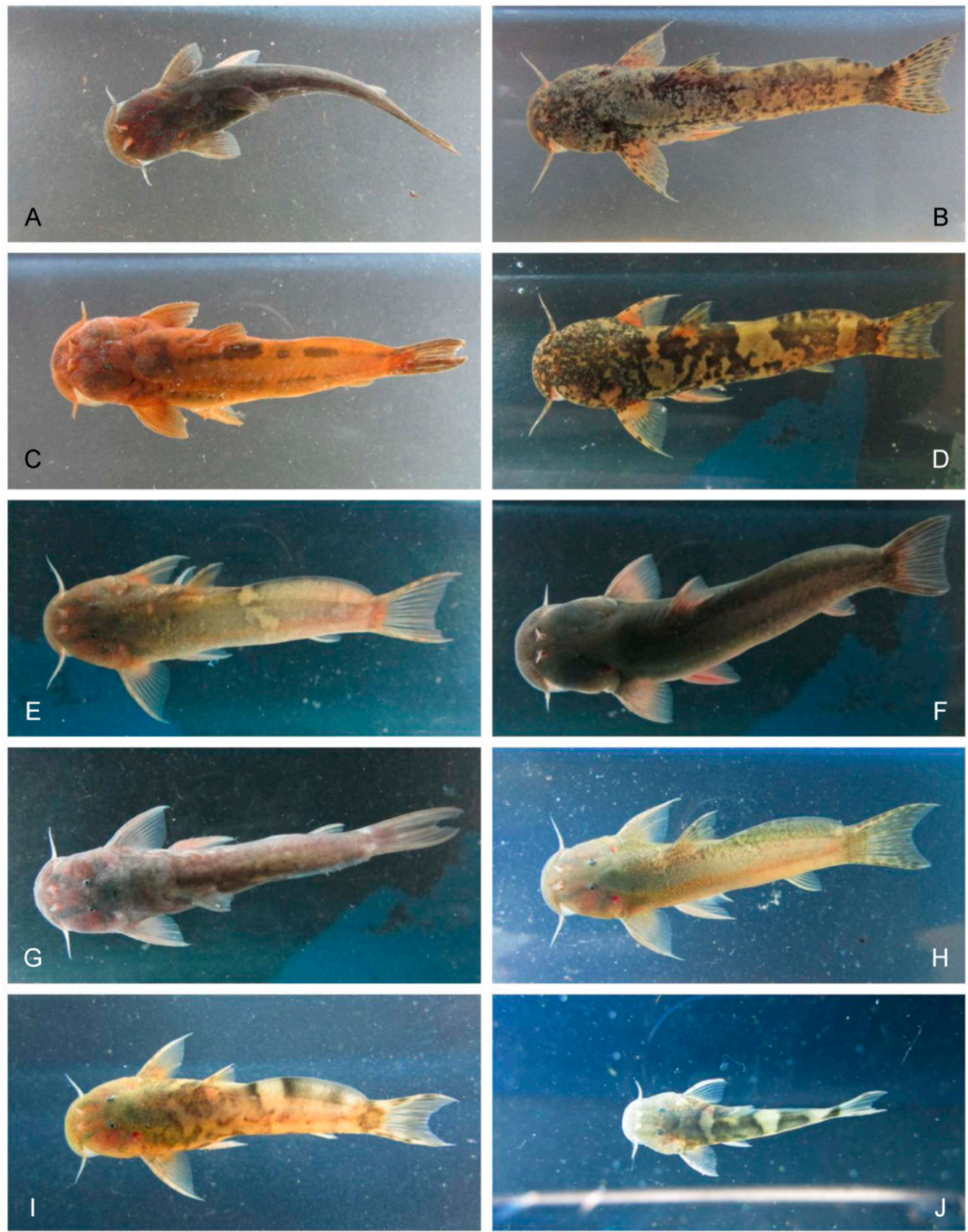

Figure 5. Species and morphotypes of genus Astroblepus collected in the upper Madre de Dios River. (A) Astroblepus sp.2 collected on Américo stream (21Q), (B) Astroblepus sp.1 collected on Unión River (20R), (C) Reddish specimen of Astroblepus sp.1 collected on Unión River (20R), (D) Astroblepus sp.1 collected on San Pedro River (19R), (E) Astroblepus mancoi collected on San Pedro River (19R), (F) Astroblepus sp.2 collected on San Pedro River (19R), (G) Astroblepus sp.1 collected on Quitacalzon stream (17Q), (H) Astroblepus aff. longifilis collected on Kosñipata River (16R), (I) Astroblepus mancoi collected on Queros River (13R), and (J) Astroblepus aff. trifasciatus collected on Salvación River (12R). 


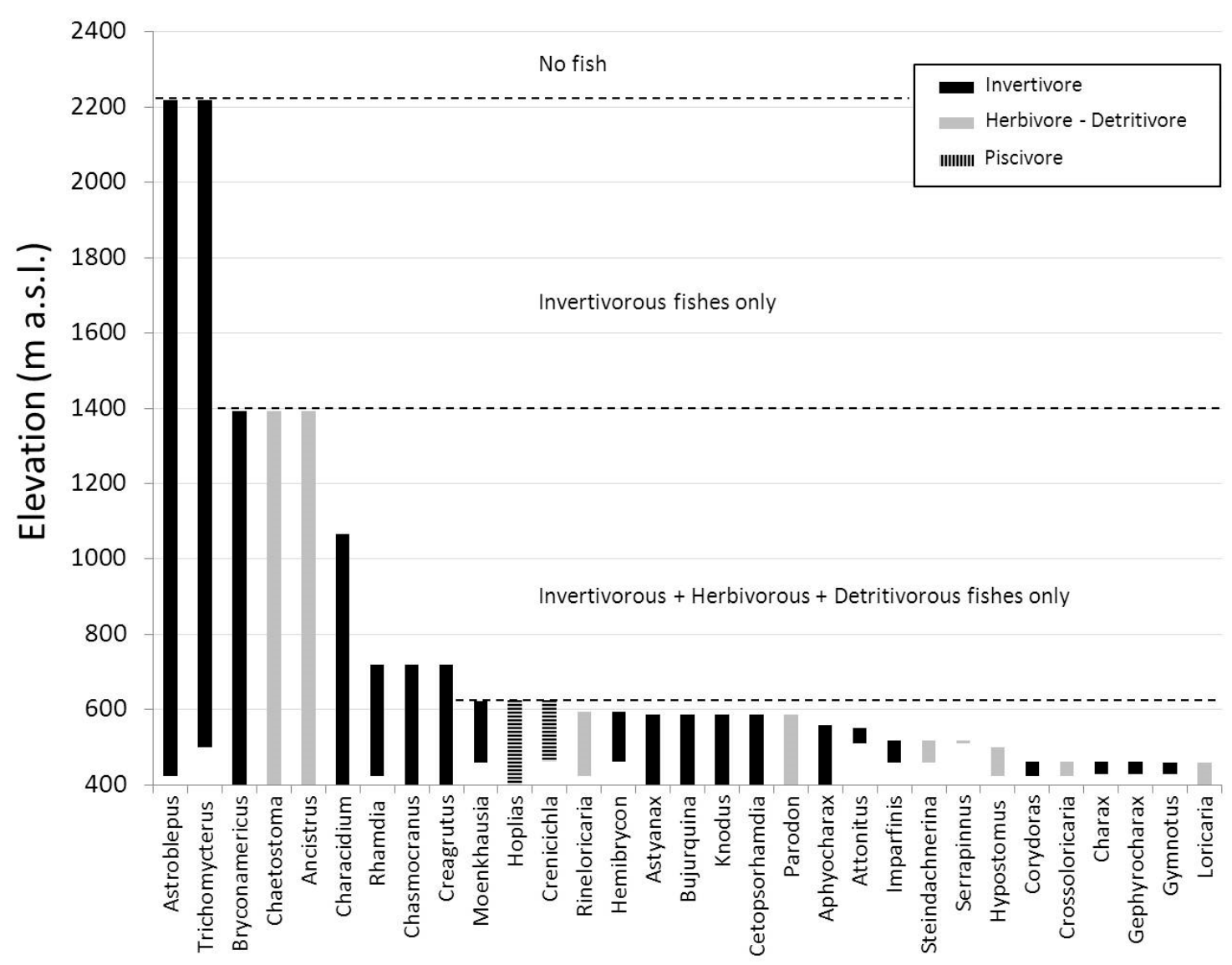

Figure 6. Elevational ranges and trophic specializations of fish species occurring at elevations $>400 \mathrm{~m}$ a.s.l. in tributary and main-channel sites within the Alto Madre de Dios watershed, south-eastern Peru.

\section{Discussion}

A gradual increase in species richness and diversity is expected along longitudinal gradients in lotic systems, associated with changes in resource availability, channel morphology, flow regime and substrate type [46,47]. Addition of species is usually related to an increase of habitats motivated for the structural diversification of the environment downstream [48]. Our study confirms this pattern (Figure 2), with the only exception of one sampling point 15 , that does not fit the trend due to its low diversity values, explained by its peculiar features as discussed below.

All the studied environmental variables were correspondent with the values reported by other works for natural and unaltered streams of this territory [6,30,49]. Quality indices of riparian and fluvial habitat (QBR and QHEI) got very high scores in all the sampling points, highlighting the good environmental quality, with some remarkable exceptions (Table 1). Riparian forest (and adjacent jungle) on the right bank of the sampling point 13, in the Queros River, was lacking due to deforestation for extensive cattle raising.

Besides, sampling point 15, located at $622 \mathrm{~m}$ a.s.l., showed significant differences both in environmental and diversity features, as already mentioned. This site belongs to a special type of aquatic ecosystem of Amazon forest known as aguajal. They are back swamp forests, defined as forest on low-lying areas outside of streams courses, only connected to them during high flood season. They are usually dominated by palms (Mauritia flexuosa), although other tree species like figs (Ficus species) can be abundant as well [50]. They also tend to be clear and acidic, in contrast to the higher turbidity and circumneutral $\mathrm{pH}$ of the streams around [51,52]. This aguajal was confined by extensive cattle pastures surrounding it and was used as drinking reservoir for cattle, showing a remarkable eutrophication. Sampling point 15 presented the described characteristics 
and showed low habitat quality indices (Table 1) and low diversity of fishes (Figure 2), with only three extant species: Moenkhausia oligolepis (70 specimens), Crenicichla semicincta (three specimens) and Hoplias malabaricus (one specimen). However, diversity might increase in the rainy season, when this habitat is connected to the river and other species present in the river could occupy this place. Species of genera Astroblepus, Trichomycterus, Bryconamericus, Ceratobranchia, Creagutus and Rhamdia are present in the nearest sampling points (Sites 14 and 16).

Because of its special and no-comparable characteristics, this peculiar sampling point has been excluded for the general comparative analysis. Although the importance of the aguajales has been widely recognized because of their ecological and social relevance [53,54], no fish species records are available on the literature. Our fish and ecological data throw some light on these poorly studied freshwater habitats.

When analyzing richness, diversity and dominance in relation with position from headwaters-downstream indicated by elevation, distance to mouth and slope, results were solid and similar for the three variables (Figure 2). The Canonical Correspondence Analyses through the marginal effect values $\left(\lambda_{\mathrm{A}}\right)$ highlighted principal role of elevation (0.59) or slope (0.44) for explaining fish distribution along the basin (Table 3). The resulting graphics were also analogous when using both variables (Figure 3). Elevation and distance to mouth are widely used for multivariate analysis $[55,56]$. Nevertheless, they do not give environmental information, they are geographical variables and indicate spatial position. Although they show strong correlation with ecologic changes, their use for ecological analysis together with environmental variables may be problematic. Instead, slope is a purely environmental variable that measures a geophysical characteristic of the site. Furthermore, it is strongly related to position along the basin but is independent from other variables, something that avoids "noise" on multivariate analyses. After validating its robustness for explaining fish distribution as well as elevation, we recommend the use of slope as alternative variable to elevation or distances to mouth/source.

Fish community composition along the basin presented two distinct groups with a clear cut-off point occurring at $700 \mathrm{~m}$ a.s.l as indicated by the ANOSIM, separating mountainous fish from piedmont communities. The boundary between both zones is marked by geomorphological changes on the basin, when it shifts from the steep mountainous streams flowing through narrow valleys, to flat and wide floodplains where river channels widen. As pointed out by SIMPER procedure Astroblepus and Trichomycterus are the most distinctive species from the mountainous streams, while Knodus was the most important species from lowlands explaining the variation in community composition (Table 2).

Fish abundance and distribution in response to environmental variables was represented using the CCA analysis and showed similar results using slope or elevation (Figure 3). The observed distribution of species along the longitudinal gradient of the basin was comparable to other fish assemblages found in rivers with similar characteristics in adjacent areas $[10,30,49]$. This biotic zonation corresponds to discontinuities in river geomorphology or abiotic conditions and are usually related to smooth transitions of abiotic factors contributing to nested patterns of assemblage composition along the altitudinal gradient [57]. The graph highlights this zonation, distributing headwater sites and their fish assemblages on the right of the diagram, related to fast running waters, steep slope, boulders and low water temperatures, opposed to middle and lowland streams on the left of the graph related to higher water temperatures, wider streams, low velocities, higher conductivity and fine substrates.

Genera Astroblepus and Trichomycterus co-occur in high reaches, being the unique species present on the sites above $1400 \mathrm{~m}$ a.s.l. These genera are adapted to headwaters, related to rocky substrates and cold, clean and well oxygenated water (Figure 3). They are benthonic species without scales and a powerful sucker mouth or opercular odontodes [58]. Nevertheless, they occasionally occur in lower areas, although their distribution is usually limited to elevations greater than 400 m.a.s.l. (Lujan et al., 2013). Bryconamericus, a rheophile genus, is the next genus joining the headwater assemblage at $1400 \mathrm{~m}$ a.s.l. (Figure 6). 
They prefer areas of moderate to strong current and present even in the torrential flows, occupying intermediate places between mountain upstream and jungle downstream $[30,59]$. We also found some Chaetostoma and Ancistrus fishes at these reaches, although they appeared closely related with lower middle section streams (Figure 3).

We found most of the species related to these middle-low reaches, distributed along the left area of the CCA (Figure 3): habitats with fine substrata, very slow water velocities, mild slope and more conductivity, related with Serrapinus, Prodontocharax, Astyanancistrus, Astyanas, Knodus and Moenkhausia, on the top-left area of the diagram (Figure 3b) [60]; other lotic sites presenting the widest habitats with highest temperature and higher $\mathrm{pH}$, were distributed on the bottom left of the diagram, related with Aphyocharax and Hemibrycon genera characids and loricarids like Rineloricaria, Chaetostoma and Ancistrus [47,59,61].

We also observed a remarkable zonation related to trophic niches (Figure 6). Headwaters were dominated exclusively by invertivorous Astroblepus (Figure 5) and Trichomycterus (Figure 4) fishes due to the scarcity of other food resources in these clean waters $[9,58]$. Although the first herbivore-detritivore Chaetostoma and Ancistrus individuals were found starting at $1400 \mathrm{~m}$ a.s.l., they were more abundant below $1000 \mathrm{~m}$ a.s.l., once the river carries enough organic matter coming from the surrounding forest offering a new trophic niche $[9,49]$. The first piscivorous species, Hoplias malabaricus and Crenicichla semicincta, were distributed around $600 \mathrm{~m}$ a.s.l. and below, first found at site 15, the aguajal, where the Moenkhausia oligolepis community was very abundant providing enough biomass to feed the predators. This distribution pattern is according with the observations of Lujan et al. [6].

According to some ecological studies and inventories carried out in this area [8,62], more than 130 species of freshwater fishes have been reported for the Alto Madre de Dios Basin. In the present study, only 78 species were collected, due to two main reasons: (1) the highest biodiversity is found on the lowest reaches of the basin and our lowest sampling was at 398 m a.s.l.; (2) electrofishing technique has some limitations on these ecosystems.

Regarding electrofishing, only wadeable stretches were sampled, whereas larger courses or deep stretches were avoided. This limitation directed our sampling efforts to smaller rivers and tributaries where the electrofisher gained efficiency [63]. Although this represents a significant impediment for carrying out a complete biological survey, also brings up new opportunities. Most of the ichthyofaunal studies undertaken in Amazonia have focused on the large rivers and commercially valuable species, therefore small and noncommercial fishes and secondary streams have been usually overlooked [64]. Guided by our limitations, part of our surveying efforts was concentrated on this poorly studied ecosystems and species.

Besides the restrictions for choosing samplings sites, fish resistance to electrofishing was significant. This resistance was favored by low water conductivity and temperature, high velocities, shelter's abundance or low visibility [65]. Furthermore, capture efficiency depended on the mobility of species: little benthic fish were collected easily, in contrast to larger, strong-swimming species that escaped the electrofishers range. However, according to other authors $[65,66]$ electrofishing is the best sampling method when your objectives are to estimate and quantify freshwater fish populations in streams and wadable rivers and to correlate these abundances with environmental features, habitat characteristics, hydrochemical parameters or other ecological measures. Besides, although electrofishing surveys have been widely achieved on the world, they have been scarce in remote places like the Alto Madre de Dios Basin due to the more complex logistics.

If we match our results with the survey carried out with seine nets by Araújo-Flores in 2013 [62] we find remarkable differences. Comparing the total 44 species reported by Araújo-Flores [62] with our 78 species only 17 of them were captured by both studies. Nevertheless, survey of Araújo-Flores focused on two rivers and its tributaries (Pilcopata and Piñi-Piñi Rivers), distributing ten sampling sites in a smaller area with a limited altitudinal range (500-600 $\mathrm{m}$ a.s.l.). If we compare our data for the three sites coinciding with the survey of Araújo-Flores (sites 7, 8 and 9), although our sampling effort was lower ( 3 vs. 10 sites) and our captured diversity smaller ( 26 vs. 44 species), we collected 15 species 
missing in the survey of Araújo-Flores [62]. Therefore, although electrofishing is not as effective in tropical streams as it is for temperate streams, it may be more effective for capturing some species that seem to be underestimated by other techniques. Consequently, as we focused on understudied small rivers and streams, catching poorly known small fish, using an uncommon technique for tropical freshwaters, our study presents new and relevant taxonomic and ecological information, providing data for some fish never captured before by previous surveys in the area.

Although our results highlight the good conservation status of the Alto Madre de Dios Basin, the territory endures severe threats: logging [22,31], gold mining [67], climate change [15,23], fossil fuel extraction [68], and hydropower projects [20,23]. The development and implementation of management plans is crucial for anticipating and mitigating future impacts. Nevertheless, the principal threat for this peculiar area, with high endemic biodiversity and very good conservation status, is the lack of knowledge regarding its fauna and flora. Studies of the fish fauna are critical to document the primary characteristics of the original communities and thereby contribute to the delimitation of appropriate conservation areas and/or to recovery strategies for degraded streams [69]. Therefore, Peruvian freshwater fish faunal inventory (including the Alto Madre de Dios River Basin) is a priority $[8,69]$. There are many remote areas, with poor accessibility, where knowledge of freshwater fish fauna is negligible and for most fish taxa basic taxonomic work is still required, not only for this area, but for all the Amazon and adjacent basins [8]. Besides, there is even less information, in some cases null, on the ecology of many species. This knowledge gap highlights the necessity of basic taxonomic works and the creation of field guides providing new research projects an essential tool [70]. Fortunately, there are some remarkable guides for the Madre de Dios Basin [52,61] and adjacent areas [71,72] that offer inestimable material about freshwater fishes in this region, although, the information in these guides is incomplete for many species. In this sense, the lack of basic knowledge may hamper the development of community-level analyses [3,73]. Although fish diversity for the hotspot is unclear yet, some papers estimate fish richness for the Andean region more than 600 species [69], with more species found at low elevations compared to higher reaches [5]. Around 2700 species have been recognized for the hotspot inside the Amazon Basin territory [74]. In contrast to richness, endemism tends to increase at higher elevations and particularly concentrates in isolated patches of habitat such as valleys and mountain tops [7]. An IUCN report evaluated fish fauna conservation status for the Tropical Andes [75] considering 666 endemic species: 13 spp. critically endangered; 33 spp. vulnerable; 36 spp. near threatened; 341 spp. least concern; 215 spp. data deficient. One of the main conclusions points out the significant information gap: $32 \%$ of the evaluated fish were poorly known.

Concerning this taxonomic constraint, freshwater fishes of high headwaters demand special attention. All of them are Andean species and live on high altitudes, areas where human settlements and their subsequent impact has a longer and more intense presence, compared with Amazonian streams [23]. We found five different species of Astroblepus (Figure 5), two of them undetermined, five species of Bryconamericus, and six species of Trichomycterus all undetermined (Figure 4). Astroblepids and trichomycterids are typically restricted in their geographical distribution and endemic to single or adjacent river systems of the Andes, and their taxonomy is poorly known and in constant revision [76-78]. Advances on the taxonomic and ecological knowledge of these high mountain species, related to tropical montane cloud forests, are mandatory for the design of conservation and management plans in the area.

According to Ortega et al. [8], there is not an official national Peruvian red list of freshwater fishes because of this lack of knowledge (despite several attempts and proposals). Although conservation lists have their limitations and critics, they represent an essential tool required for protecting biodiversity [79]. Therefore, it is imperative to continue with the study of freshwater fish species in Peru with the aim of improving management actions and conservation plans. 
In the light of this scenario where no Andean-Amazon Basin will remain untouched, the Alto Madre de Dios River Basin still preserves healthy ecosystems, with mild human impacts affecting some stretches, but showing a good environmental quality overall. Therefore, this makes the basin a perfect candidate for being preserved and considered as a reference basin for these seriously endangered ecosystems.

Author Contributions: Conceptualization, R.M. and I.T.; methodology, R.M., I.T. and A.R.-M.; formal analysis, A.R.-M. and I.T.; investigation, R.M., I.T., A.P.-d.-C. and J.A.-F.; data curation, I.T. and R.M.; writing—original draft preparation, I.T. and R.M.; writing—review and editing, R.M., I.T., A.P.-d.-C., A.R.-M., J.A.-F. and H.O.; visualization, J.A.-F. and I.T.; supervision, A.P.-d.-C. and R.M.; project administration, R.M. and A.P.-d.-C.; funding acquisition, R.M. All authors have read and agreed to the published version of the manuscript.

Funding: This research was funded by Government of Spain, Ministry of Foreign Affairs and Cooperation, AECID (Code A1/040396/11) and Asociación de Amigos Universidad de Navarra.

Institutional Review Board Statement: Not applicable.

Informed Consent Statement: Not applicable.

Data Availability Statement: The data presented in this study are available on request from the corresponding author. The data are not publicly available due to authors are preparing a dataset of these and another fish data from the Andean rivers that will be published in the next months.

Acknowledgments: Invaluable field assistance and friendship was provided by Américo Quispe. We are grateful for the unreserved cooperation of Hugo Pepper, who provided logistic and data support. Robin Van Loon helps us on the English revision. We are grateful to Miles Silman for their useful comments. We thank the members of the Department of Ichthyology of MUSM for their help and assistance. The Asociación para la Conservación de la Cuenca Amazónica (ACCA), kindly provided valuable information, collaboration and lodging during our fieldwork. We also wish to thank Ronald Mendoza for helping to prepare the map figure.

Conflicts of Interest: The authors declare no conflict of interest. The funders had no role in the design of the study; in the collection, analyses, or interpretation of data; in the writing of the manuscript, or in the decision to publish the results.

\section{References}

1. Gozlan, R.E.; Britton, J.R.; Cowx, I.G.; Copp, G.H. Current Knowledge on Non-Native Freshwater Fish Introductions. J. Fish Biol. 2010, 76, 751-786. [CrossRef]

2. Ricciardi, A.; Rasmussen, J.B. Extinction Rates of North American Freshwater Fauna. Conserv. Biol. 1999, 13, 1220-1222. [CrossRef]

3. Miqueleiz, I.; Böhm, M.; Ariño, A.H.; Miranda, R. Assessment Gaps and Biases in Knowledge of Conservation Status of Fishes. Aquat. Conserv. Mar. Freshw. Ecosyst. 2020, 30, 225-236. [CrossRef]

4. Allan, J.D.; Flecker, A.S. Biodiversity Conservation in Running Waters. BioScience 1993, 43, 32. [CrossRef]

5. Oberdorff, T.; Dias, M.S.; Jézéquel, C.; Albert, J.S.; Arantes, C.C.; Bigorne, R.; Carvajal-Vallejos, F.M.; de Wever, A.; Frederico, R.G.; Hidalgo, M.; et al. Unexpected Fish Diversity Gradients in the Amazon Basin. Sci. Adv. 2019, 5, eaav8681. [CrossRef] [PubMed]

6. Lujan, N.K.; Roach, K.A.; Jacobsen, D.; Winemiller, K.O.; Vargas, V.M.; Ching, V.R.; Maestre, J.A. Aquatic Community Structure across an Andes-to-Amazon Fluvial Gradient. J. Biogeogr. 2013, 40, 1715-1728. [CrossRef]

7. Bax, V.; Francesconi, W. Conservation Gaps and Priorities in the Tropical Andes Biodiversity Hotspot: Implications for the Expansion of Protected Areas. J. Environ. Manag. 2019, 232, 387-396. [CrossRef]

8. Ortega, H.; Hidalgo, M.; Trevejo, G.; Correa, E.; Cortijo, A.M.; Meza, V.; Espino, J. Lista Anotada de Los Peces de Aguas Continentales Del Perú; Ministerio del Ambiente, Dirección General de Diversidad Biológica and Museo de Historia Natural, UNMSM: Lima, Peru, 2012; ISBN 9786124605321.

9. Benejam, L.; Tobes, I.; Brucet, S.; Miranda, R. Size Spectra and Other Size-Related Variables of River Fish Communities: Systematic Changes along the Altitudinal Gradient on Pristine Andean Streams. Ecol. Indic. 2018, 90, 366-378. [CrossRef]

10. Carvajal-Quintero, J.D.; Escobar, F.; Alvarado, F.; Villa-Navarro, F.A.; Jaramillo-Villa, Ú.; Maldonado-Ocampo, J.A. Variation in Freshwater Fish Assemblages along a Regional Elevation Gradient in the Northern Andes, Colombia. Ecol. Evol. 2015, 5, 2608-2620. [CrossRef]

11. Pitman, N.C.A.; Salas, K.; Loyola Azáldegui, M.D.C.; Vigo, G.; Lutz, D.A. Historia e Impacto de La Literatura Científica Del Departamento de Madre de Dios, Perú. Rev. Peru. Biol. 2008, 15, 15-22. [CrossRef]

12. Albert, J.S.; Tagliacollo, V.A.; Dagosta, F. Diversification of Neotropical Freshwater Fishes. Annu. Rev. Ecol. Evol. Syst. 2020, 51. [CrossRef] 
13. Townsend-Small, A.; McClain, M.E.; Hall, B.; Noguera, J.L.; Llerena, C.A.; Brandes, J.A. Suspended Sediments and Organic Matter in Mountain Headwaters of the Amazon River: Results from a 1-Year Time Series Study in the Central Peruvian Andes. Geochim. Cosmochim. Acta 2008, 72, 732-740. [CrossRef]

14. Laraque, A.; Bernal, C.; Bourrel, L.; Darrozes, J.; Christophoul, F.; Armijos, E.; Fraizy, P.; Pombosa, R.; Guyot, J.L. Sediment Budget of the Napo River, Amazon Basin, Ecuador and Peru. Hydrol. Process. 2009, 23, 3509-3524. [CrossRef]

15. Malhi, Y.; Roberts, J.T.; Betts, R.A.; Killeen, T.J.; Li, W.; Nobre, C.A. Climate Change, Deforestation, and the Fate of the Amazon. Science 2008, 319, 169-172. [CrossRef]

16. Aldrich, S.; Walker, R.; Simmons, C.; Caldas, M.; Perz, S. Contentious Land Change in the Amazon's Arc of Deforestation. Ann. Assoc. Am. Geogr. 2012, 102, 103-128. [CrossRef]

17. Garcia, A.S.; Vívian, V.M.; Rizzo, R.; West, P.; Gerber, J.S.; Engstrom, P.M.; Maria, M.V. Assessing Land Use/Cover Dynamics and Exploring Drivers in the Amazon's Arc of Deforestation through a Hierarchical, Multi-Scale and Multi-Temporal Classification Approach. Remote Sens. Appl. Soc. Environ. 2019, 15, 100233. [CrossRef]

18. Brooks, T.M.; Mittermeier, R.A.; Mittermeier, C.G.; da Fonseca, G.A.B.; Rylands, A.B.; Konstant, W.R.; Flick, P.; Pilgrim, J.D.; Oldfield, S.; Magin, G.; et al. Habitat Loss and Extinction in the Hotspots of Biodiversity. Conserv. Biol. 2002, 16, 909-923. [CrossRef]

19. Restrepo, J.D.; Kettner, A.J.; Syvitski, J.P.M. Recent Deforestation Causes Rapid Increase in River Sediment Load in the Colombian Andes. Anthropocene 2015, 10, 13-28. [CrossRef]

20. Almeida, R.M.; Shi, Q.; Gomes-Selman, J.M.; Wu, X.; Xue, Y.; Angarita, H.; Barros, N.; Forsberg, B.R.; García-Villacorta, R.; Hamilton, S.K.; et al. Reducing Greenhouse Gas Emissions of Amazon Hydropower with Strategic Dam Planning. Nat. Commun. 2019, 10, 4281. [CrossRef]

21. Anderson, E.P.; Jenkins, C.N.; Heilpern, S.; Maldonado-Ocampo, J.A.; Carvajal-Vallejos, F.M.; Encalada, A.C.; Rivadeneira, J.F.; Hidalgo, M.; Cañas, C.M.; Ortega, H.; et al. Fragmentation of Andes-to-Amazon Connectivity by Hydropower Dams. Sci. Adv. 2018, 4, eaao1642. [CrossRef]

22. Yu, D.W.; Hendrickson, T.; Castillo, A. Ecotourism and Conservation in Amazonian Peru: Short-Term and Long-Term Challenges. Environ. Conserv. 1997, 24, 130-138. [CrossRef]

23. Encalada, A.C.; Flecker, A.S.; Poff, N.L.; Suárez, E.; Herrera-R, G.A.; Ríos-Touma, B.; Jumani, S.; Larson, E.I.; Anderson, E.P. A Global Perspective on Tropical Montane Rivers. Science 2019, 365, 1124-1129. [CrossRef]

24. Anderson, E.P.; Maldonado-Ocampo, J.A. A Regional Perspective on the Diversity and Conservation of Tropical Andean Fishes. Conserv. Biol. 2011, 25, 30-39. [CrossRef]

25. Gentry, A. Changes in Plant Community Diversity and Floristic Composition on Environmental and Geographical Gradients. Ann. Mo. Bot. Gard. 1988, 75, 1-34. [CrossRef]

26. McCoy, E.D. The Distribution of Insects along Elevational Gradients. Oikos 1990, 58, 313. [CrossRef]

27. Fu, C.; Hua, X.; Li, J.; Chang, Z.; Pu, Z.; Chen, J. Elevational Patterns of Frog Species Richness and Endemic Richness in the Hengduan Mountains, China: Geometric Constraints, Area and Climate Effects. Ecography 2006, 29, 919-927. [CrossRef]

28. Montaño-Centellas, F.A.; McCain, C.; Loiselle, B.A. Using Functional and Phylogenetic Diversity to Infer Avian Community Assembly along Elevational Gradients. Glob. Ecol. Biogeogr. 2020, 29, 232-245. [CrossRef]

29. Lessmann, J.; Guayasamin, J.M.; Casner, K.L.; Flecker, A.S.; Funk, W.C.; Ghalambor, C.K.; Gill, B.A.; Jácome-Negrete, I.; Kondratieff, B.C.; Poff, L.N.; et al. Freshwater Vertebrate and Invertebrate Diversity Patterns in an Andean-Amazon Basin: Implications for Conservation Efforts. Neotrop. Biodivers. 2016, 2, 99-114. [CrossRef]

30. Jaramillo-Villa, Ú.; Maldonado-Ocampo, J.A.; Escobar, F. Altitudinal Variation in Fish Assemblage Diversity in Streams of the Central Andes of Colombia. J. Fish Biol. 2010, 76, 2401-2417. [CrossRef]

31. Salvador, S.; Clavero, M.; Leite Pitman, R. Large Mammal Species Richness and Habitat Use in an Upper Amazonian Forest Used for Ecotourism. Mamm. Biol. Z. Säugetierkunde 2011, 76, 115-123. [CrossRef]

32. Thieme, M.L.; Lehner, B.; Abell, R.; Hamilton, S.K.; Kellndorfer, J.; Powell, G.; Riveros, J.C. Freshwater Conservation Planning in Data-Poor Areas: An Example from a Remote Amazonian Basin (Madre de Dios River, Peru and Bolivia). Biol. Conserv. 2007, 135, 484-501. [CrossRef]

33. Fricke, R.; Eschmeyer, W.N.; van der Laan, R. Eschmeyer's Catalog of Fishes: Genera, Species, References. Available online: http:/ / researcharchive.calacademy.org/research/ichthyology/catalog/fishcatmain.asp (accessed on 5 May 2020).

34. Radinger, J.; Britton, J.R.; Carlson, S.M.; Magurran, A.E.; Alcaraz-Hernández, J.D.; Almodóvar, A.; Benejam, L.; Fernández-Delgado, C.; Nicola, G.G.; Oliva-Paterna, F.J.; et al. Effective Monitoring of Freshwater Fish. Fish Fish. 2019, faf.12373. [CrossRef]

35. Godinho, F.N.; Ferreira, M.T.; Santos, J.M. Variation in Fish Community Composition along an Iberian River Basin from Low to High Discharge: Relative Contributions of Environmental and Temporal Variables. Ecol. Freshw. Fish 2000, 9, 22-29. [CrossRef]

36. Clarke, K.R. Non-parametric Multivariate Analyses of Changes in Community Structure. Aust. J. Ecol. 1993, 18, 117-143. [CrossRef]

37. Bray, J.R.; Curtis, J.T. An Ordination of the Upland Forest Communities of Southern Wisconsin. Ecol. Monogr. 1957, 27, 325-349. [CrossRef]

38. Lepš, J.; Šmilauer, P. Multivariate Analysis of Ecological Data Using CANOCO; Cambridge University Press: Cambridge, UK, 2003.

39. Braak, C.J.F.F.; Verdonschot, P.F.M.M. Canonical Correspondence Analysis and Related Multivariate Methods in Aquatic Ecology. Aquat. Sci. 1995, 57, 255-289. [CrossRef] 
40. ter Braak, C.J.F.; Šmilauer, P. Canoco Reference Manual and CanoDraw for Windows User's Guide. 2002, p. 500. Available online: https:/ / library.wur.nl/WebQuery/wurpubs/reports/341885 (accessed on 19 May 2019).

41. Blanchet, F.G.; Legendre, P.; Borcard, D. Forward selection of explanatory variables. Ecology 2008, 89, 2623-2632. [CrossRef]

42. R Development Core Team R: A Language and Environment for Statistical Computing. Available online: https://www.r-project. org/ (accessed on 19 May 2019).

43. Oksanen, J.; Blanchet, F.G.; Friendly, M.; Kindt, R.; Legendre, P.; McGlinn, D.; Minchin, P.R.; Ohara, R.B.; Simpson, G.L.; Solymos, P.; et al. The Vegan Package. Community Ecology Package; Version 2.5-7. 2020. Available online: https://cran.r-project.org/web/ packages/vegan/index.html (accessed on 19 September 2020).

44. Lujan, N.K.; Winemiller, K.O.; Armbruster, J.W. Trophic Diversity in the Evolution and Community Assembly of Loricariid Catfishes. BMC Evol. Biol. 2012, 12. [CrossRef]

45. Luz-Agostinho, K.D.G.; Agostinho, A.A.; Gomes, L.C.; Júlio, H.F. Influence of Flood Pulses on Diet Composition and Trophic Relationships among Piscivorous Fish in the Upper Paraná River Floodplain. Hydrobiologia 2008, 607, 187-198. [CrossRef]

46. Hoeinghaus, D.J.; Winemiller, K.O.; Taphorn, D.C. Compositional Change in Fish Assemblages along the Andean PiedmontLlanos Floodplain Gradient of the Río Portuguesa, Venezuela. Neotrop. Ichthyol. 2004, 2, 85-92. [CrossRef]

47. Alexandre, C.V.; Esteves, K.E.; de Moura e Mello, M.A.M. Analysis of Fish Communities along a Rural-Urban Gradient in a Neotropical Stream (Piracicaba River Basin, São Paulo, Brazil). Hydrobiologia 2010, 641, 97-114. [CrossRef]

48. Leunda, P.M.; Sistiaga, M.; Oscoz, J.; Miranda, R. Ichthyofauna of a Near-Natural Pyrenean River: Spatio-Temporal Variability and Reach-Scale Habitat. Environ. Eng. Manag. J. 2012, 11, 1111-1124. [CrossRef]

49. Tobes, I.; Gaspar, S.; Peláez-Rodríguez, M.; Miranda, R. Spatial Distribution Patterns of Fish Assemblages Relative to Macroinvertebrates and Environmental Conditions in Andean Piedmont Streams of the Colombian Amazon. Inland Waters 2016, 6, 89-104. [CrossRef]

50. Hamilton, S.K.; Kellndorfer, J.; Lehner, B.; Tobler, M. Remote Sensing of Floodplain Geomorphology as a Surrogate for Biodiversity in a Tropical River System (Madre de Dios, Peru). Geomorphology 2007, 89, 23-38. [CrossRef]

51. Manzi, M.; Coomes, O.T. Managing Amazonian Palms for Community Use: A Case of Aguaje Palm (Mauritia Flexuosa) in Peru. For. Ecol. Manag. 2009, 257, 510-517. [CrossRef]

52. Goulding, M.; Cañas, C.; Barthem, R.; Forsberg, B.; Ortega, H. Las Fuentes Del Amazonas: Ríos, Vida y Conservación de La Cuenca Del Madre de Dios; ACCA-ACA: Lima, Peru, 2003.

53. Cotta, J.N. Contributions of Local Floodplain Resources to Livelihoods and Household Income in the Peruvian Amazon. For. Policy Econ. 2015, 59, 35-46. [CrossRef]

54. van der Hoek, Y.; Solas, S.Á.; Peñuela, M.C. The Palm Mauritia Flexuosa, a Keystone Plant Resource on Multiple Fronts. Biodivers. Conserv. 2019, 28, 539-551. [CrossRef]

55. Zhu, R.; Li, Q.; Wang, W.; Chu, L.; Yan, Y. Effects of Local, River-Network and Catchment Factors on Fish Assemblages in the Headwater Streams of the Xin'an Basin, China. J. Freshw. Ecol. 2017, 32, 300-313. [CrossRef]

56. Trujillo-Jiménez, P.; López-López, E.; Díaz-Pardo, E.; Camargo, J.A. Patterns in the Distribution of Fish Assemblages in Río Amacuzac, Mexico: Influence of Abiotic Factors and Biotic Factors. Fish Biol. Fish. 2010, 20, 457-469. [CrossRef]

57. Tejerina-Garro, F.L.; Maldonado, M.; Ibañez, C.; Pont, D.; Roset, N.; Oberdorff, T. Effects of Natural and Anthropogenic Environmental Changes on Riverine Fish Assemblages: A Framework for Ecological Assessment of Rivers. Braz. Arch. Biol. Technol. 2005, 48, 91-108. [CrossRef]

58. Schaefer, S.A.; Arroyave, J. Rivers as Islands: Determinants of the Distribution of Andean Astroblepid Catfishes. J. Fish Biol. 2010, 77, 2373-2390. [CrossRef]

59. Miranda, R.; Tobes, I.; Gaspar, S.; Peláez-Rodríguez, M. Patterns in the Distribution of Fish Assemblages and Their Association with Habitat Variables in the Suaza River on Its Way through the Cueva de Los Guácharos National Park, Colombia. Écoscience 2018, 25, 85-95. [CrossRef]

60. Pouilly, M.; Barrera, S.; Rosales, C. Changes of Taxonomic and Trophic Structure of Fish Assemblages along an Environmental Gradient in the Upper Beni Watershed (Bolivia). J. Fish Biol. 2006, 68, 137-156. [CrossRef]

61. Barthem, R.; Goulding, M.; Forsberg, B.; Cañas, C.; Ortega, H. Ecología Acuática Del Rio Madre de Dios: Bases Científicas Para La Conservación de Cabeceras Andino-Amazónicas; ACCA-ACA: Lima, Peru, 2003.

62. Araujo Flores, J.M. Caracterización de La Biodiversidad Acuática En La Cuenca Andino-Amazónica de Madre de Dios—Perú; Universidad de Huelva: Huelva, Spain, 2016.

63. Allard, L.; Grenouillet, G.; Khazraie, K.; Tudesque, L.; Vigouroux, R.; Brosse, S. Electrofishing Efficiency in Low Conductivity Neotropical Streams: Towards a Non-Destructive Fish Sampling Method. Fish. Manag. Ecol. 2014, 21, 234-243. [CrossRef]

64. Mendonça, F.P.; Magnusson, W.E.; Zuanon, J. Relationships between Habitat Characteristics and Fish Assemblages in Small Streams of Central Amazonia. Copeia 2005, 2005, 751-764. [CrossRef]

65. Zalewski, M. The Estimate of Fish Density and Biomass in Rivers on the Basis of Relationships between Specimen Size and Efficiency of Electrofishing. Fish. Res. 1985, 3, 147-155. [CrossRef]

66. Meador, M.R.; McIntyre, J.P.; Pollock, K.H. Assessing the Efficacy of Single-Pass Backpack Electrofishing to Characterize Fish Community Structure. Trans. Am. Fish. Soc. 2003, 132, 39-46. [CrossRef]

67. Swenson, J.J.; Carter, C.E.; Domec, J.-C.; Delgado, C.I. Gold Mining in the Peruvian Amazon: Global Prices, Deforestation, and Mercury Imports. PLoS ONE 2011, 6, e18875. [CrossRef] 
68. Finer, M.; Orta-Martínez, M. A Second Hydrocarbon Boom Threatens the Peruvian Amazon: Trends, Projections, and Policy Implications. Environ. Res. Lett. 2010, 5, 014012. [CrossRef]

69. Tognelli, M.F.; Anderson, E.P.; Jiménez-Segura, L.F.; Chuctaya, J.; Chocano, L.; Maldonado-Ocampo, J.A.; Mesa-Salazar, L.; Mojica, J.I.; Carvajal-Vallejos, F.M.; Correa, V.; et al. Assessing Conservation Priorities of Endemic Freshwater Fishes in the Tropical Andes Region. Aquat. Conserv. Mar. Freshw. Ecosyst. 2019, 29, 1123-1132. [CrossRef]

70. Giangrande, A. Biodiversity, Conservation, and the "Taxonomic Impediment". Aquat. Conserv. Mar. Freshw. Ecosyst. 2003, 13, 451-459. [CrossRef]

71. Galvis, G.; Mojica, J.I.; Duque, S.R.; Castellanos, C.; Sánchez-Duarte, P.; Arce, M.; Gutiérrez, Á.; Jiménez, L.F.; Santos, M.; Vejarano, S.; et al. Peces Del Medio Amazonas, Región de Leticia; Conservación Internacional; Editorial Panamericana, Formas e Impresos: Bogotá, Colombia, 2006.

72. Carvalho, T.P.; Flores, J.A.; Espino, J.; Trevejo, G.; Ortega, H.; Jerep, F.C.; Reis, R.E.; Albert, J.S. Fishes from the Las Piedras River, Madre de Dios Basin, Peruvian Amazon. Check List 2012, 8, 973. [CrossRef]

73. Dubois, A. The Relationships between Taxonomy and Conservation Biology in the Century of Extinctions. Comptes Rendus Biol. 2003, 326, 9-21. [CrossRef]

74. Jézéquel, C.; Tedesco, P.A.; Darwall, W.; Dias, M.S.; Frederico, R.G.; Hidalgo, M.; Hugueny, B.; Maldonado-Ocampo, J.; Martens, K.; Ortega, H.; et al. Freshwater Fish Diversity Hotspots for Conservation Priorities in the Amazon Basin. Conserv. Biol. 2020, 34, 956-965. [CrossRef]

75. Tognelli, M.F.; Lasso, C.A.; Bota-Sierra, C.A.; Jiménez-Segura, L.F.; Cox, N.A. Estado de Conservación y Distribución de la Biodiversidad de Agua Dulce en los Andes Tropicales; UICN: Gland, Switzerland, 2016; ISBN 978-2-8317-1791-3.

76. Donin, L.M.; Ferrer, J.; Carvalho, T.P. Taxonomical Study of Trichomycterus (Siluriformes: Trichomycteridae) from the Ribeira de Iguape River Basin Reveals a New Species Recorded in the Early 20th Century. J. Fish Biol. 2020, 96, 886-904. [CrossRef]

77. Ochoa, L.E.; Melo, B.F.; García-Melo, J.E.; Maldonado-Ocampo, J.A.; Souza, C.S.; Albornoz-Garzón, J.G.; Conde-Saldaña, C.C.; Villa-Navarro, F.; Ortega-Lara, A.; Oliveira, C. Species Delimitation Reveals an Underestimated Diversity of Andean Catfishes of the Family Astroblepidae (Teleostei: Siluriformes). Neotrop. Ichthyol. 2020, 18, 1-19. [CrossRef]

78. Schaefer, S.A.; Chakrabarty, P.; Geneva, A.J.; Sabaj Pérez, M.H. Nucleotide Sequence Data Confirm Diagnosis and Local Endemism of Variable Morphospecies of Andean Astroblepid Catfishes (Siluriformes: Astroblepidae). Zool. J. Linn. Soc. 2011, 162, 90-102. [CrossRef]

79. Burgass, M.J.; Arlidge, W.N.S.; Addison, P.F.E. Overstating the Value of the IUCN Red List for Business Decision-Making. Conserv. Lett. 2018, 11, 1-8. [CrossRef] 